\title{
New sources of arbutin: Onobrychis nitida and Onobrychis galegifolia
}

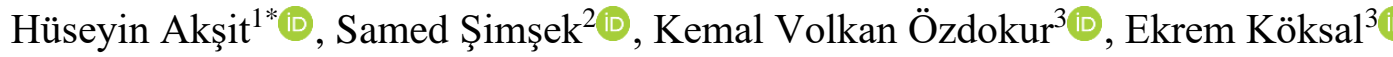 \\ ${ }^{1}$ Erzincan Binali Yıldırım University, Faculty of Pharmacy, Analytical Chemistry Dept. Erzincan, 24100 \\ ${ }^{2}$ Erzincan Binali Yıldırım University, Çayırlı Vocational School, Medical Services and Techniques Dept. \\ Erzincan, 24500 \\ ${ }^{3}$ Erzincan Binali Yıldırım University, Faculty of Science and Art, Chemistry Dept. Erzincan, 24100
}

Geliş / Received: 12.12.2019, Kabul / Accepted: 25.12.2019

\begin{abstract}
Arbutin (4-Hydroxyphenyl- $\beta$ - $D$-glucopyranoside) is a mono glycosidic form of hydroquinone and has been widely used in cosmetics for a long time due to skin whitening and freckle removing properties. In this study, arbutin was isolated from the methanol extract of Onobrychis galegifolia using flash chromatography. The structure of arbutin was elucidated by ${ }^{1} \mathrm{H}$ and ${ }^{13} \mathrm{C}-\mathrm{NMR}$ spectroscopy and as well as $2 \mathrm{D}$ NMR techniques. In addition, quantitative analysis of arbutin found in $O$. galegifolia and $O$. nitida species was done using HPLCDAD. According to the results, the arbutin content of methanol extracts of $O$. galegifolia and $O$. nitida was found 212.02 and $196.46 \mathrm{mg} / \mathrm{g}$ extract respectively. In addition, the arbutin content of cold-water extracts of $O$. galegifolia and $O$. nitida was found 128.2 and $99.40 \mathrm{mg} / \mathrm{g}$ extract. The amount of arbutin in dry weights was calculated for about $5.66 \%$ to $6.86 \%$.
\end{abstract}

Keywords: Arbutin, Onobrychis nitida, Onobrychis galegifolia

\section{Arbutin'in yeni kaynakları: Onobrychis nitida and Onobrychis galegifolia}

\section{$\ddot{\mathbf{O} z}$}

Arbutin (4-Hidroksifenil- $\beta$ - $D$-glukopiranozit), hidrokinonun mono glikozidik formudur ve cilt beyazlatma ve çil giderme özellikleri nedeniyle kozmetiklerde uzun süredir yaygın olarak kullanılmaktadır. Bu çalışmada; arbutin flash kromatografi kullanılarak Onobrychis galegifolia'nın metanol ekstraktından izole edilmiştir. Arbutin yapıs1, ${ }^{1} \mathrm{H}$ ve ${ }^{13} \mathrm{C}$-NMR spektroskopisi ve ayrıca 2D NMR teknikleri ile aydınlatıldı. Ek olarak, $O$. galegifolia ve $O$. nitida türlerinde bulunan arbutinin kantitatif analizi HPLC-DAD kullanılarak yapıldı. Sonuçlara göre, $O$. galegifolia ve $O$. nitida'nın metanol ekstraktlarının arbutin içeriği sırasıyla 212.02 ve 196.46 mg/g ekstrakt olarak bulundu. Ayrıca, O. galegifolia ve $O$. nitida'nın soğuk su ekstraktlarının arbutin içeriği 128.2 ve 99.40 mg/g ekstrakt olarak bulundu. Kuru ağırlıklardaki arbutin miktarı, yaklaşı\% 5.66 ila\% 6.86 arasinda hesaplandi.

Anahtar Kelimeler: Arbutin, Onobrychis nitida, Onobrychis galegifolia 


\section{Introduction}

The Onobrychis genus comprises a few agroeconomically important forage legume species and some Onobrychis species are cultivated in many parts of the world because of their flavor and drought resistance as a portion of animal food. Recent studies show that it has highly beneficial properties for animals because of its tannin and polyphenolic composition. The phenolic contents of sainfoins are assumed to contribute to its nutritive value and bioactive properties The Onobrychis species (sainfoins) known as "korunga" in Turkey. Onobrychis nitida, which is an endemic species to Turkey, and Onobrychis galegifolia also known as "Firat korungası" and "darp korungası", respectively. The objectives of the current study were, to determine the arbutin contents of two sainfoin species ( $O$. nitida and $O$. galegifolia) growing in the flora of Erzincan to contribute to knowledge about chemical content these two species.

\section{Material and Methods}

\subsection{Plant materials}

Plant materials was collected İliç-Kemah Road $32^{\text {th }} \mathrm{km}$ in June 2018 from jipsy rocks, Erzincan. Plant materials were authenticated by Prof. Dr. Ali Kandemir, a voucher specimen was deposited in Erzincan Binali Yıldırım University Herbarium.

\subsection{General experimental process}

${ }^{1} \mathrm{H},{ }^{13} \mathrm{C}$, DEPT, HETCOR and COSY NMR spectra were recorded on a Bruker Avance II $400 \mathrm{MHz}$ spectrometer in DMSO-d6. Analytical HPLC analysis was carried out on a Thermo Scientific Ultimate 3000 HPLC with Agilent Zorbax C18 column (4.6X250 $\mathrm{mm}, 5 \mu \mathrm{m})$. The arbutin was detected at 290 $\mathrm{nm}$ with a linear gradient from 5 to $55 \% \mathrm{ACN}$ in $0.5 \%$ phosphoric acid in water for $15 \mathrm{~min}$. The column temperature was set at $35{ }^{\circ} \mathrm{C}$. Flash chromatography separation of arbutin was carried out using a Buchi Reveleris X2 instrument with an Ecoflex silica gel packed column (40 g, $50 \mu \mathrm{m})$.

\subsection{Isolation of Arbutin}

The crude methanol extract $(8.0 \mathrm{~g})$ was dissolved in $30 \mathrm{~mL}$ of water and non-soluble parts were removed. An aliquot of $10 \mathrm{~mL}$ of this solution was injected into the reverse phase column (30x150 mm). $250 \mathrm{~mL}$ of following mixtures of water and methanol were passed column: 100:0 (F-1), 90:10 (F-2), 80:20 (F-3), 70:30 (F-4), 60:40 (F-5), 50:50 (F-6) and 40:60 (F-7). The F-1 and F-2 combined according to TLC basis (See Figure 1) then concentrated under vacuum to give an arbutin-rich mixture $(3 \mathrm{~g})$. The mixture was loaded onto to flash chromatography system and the extract was eluted with a linear gradient from 100:0 (A: B) to 80:20 A: B for $30 \mathrm{~min}$ at a flow rate of $20 \mathrm{~mL} / \mathrm{min}$. Here, $\mathrm{A}$ was a mixture of EtOAc: water: acetic acid $(7: 1.5: 0.5)$ and $B$ was methanol. The automatically collected fractions (18-21 min) based on the signals of ELSD were pooled, concentrated to the dryness (See Figure 1). Arbutin was obtained as white crystalline (600 $\mathrm{mg}$ ).

\subsection{Quantification of arbutin}

Ten mg of arbutin accurately weighed and solved in $10 \mathrm{~mL}$ of deionized water to get a 1000 ppm stock solution. Five concentrations were prepared to contain 500, 250, 125, 62.5 and $31.25 \mathrm{ppm}$ by serial dilution. After analyzing these concentrations, a calibration curve was obtained with an $\mathrm{R}^{2}=0.9999$ value and $y=0.0577 x+0.095$ equation. LOQ and LOD were calculated as 0.83 and $0.33 \mathrm{ppm}$, respectively. The extraction procedure was as 
follows: $4 \mathrm{~g}$ of well-grounded aerial parts of plant materials were extracted in $100 \mathrm{~mL}$ of methanol in the ultrasonic bath for $30 \mathrm{~min}$ in ambient temperature. The solvent was removed by filtration and fresh $100 \mathrm{ml}$ of methanol was added. The process was repeated triple. The same extraction process was repeated for cold-water extracts. The solvents were evaporated to the dryness then a $20 \mathrm{mg} / \mathrm{mL}$ stock solution was prepared and filtrated using $0.22 \mu \mathrm{m}$ syringe filter. The methanol and cold-water extracts were diluted 1:20 and 1:10 respectively. The final solutions were injected into HPLC. The arbutin contents of extract were expressed as mg arbutin/g extract and \% arbutin content of dry biomass. The HPLC-UV chromatograms of standard arbutin and plant extracts were given in Figure 2.
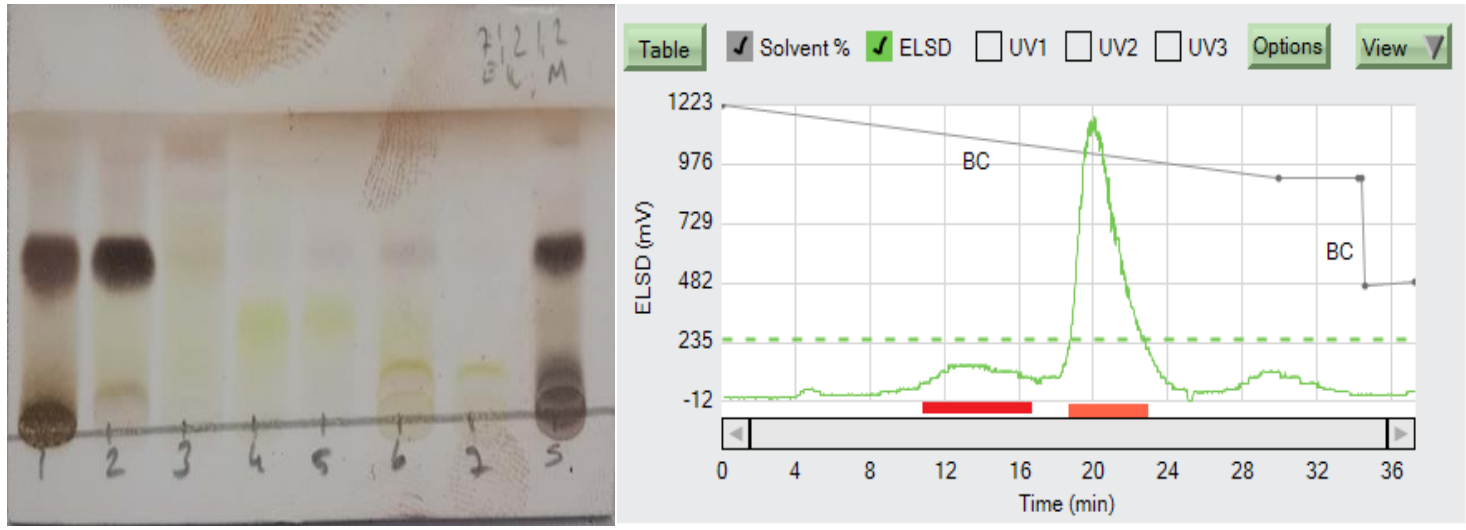

Figure 1. TLC view and Flash chromatography chromatogram of C18 fraction F-1 and F-2

\section{Results}

\subsection{NMR analysis:}

The ${ }^{1} \mathrm{H}$ spectra of arbutin were exhibited two doublets with $J=8.86 \mathrm{~Hz}$ at 6.67 and $6.86 \mathrm{ppm}$, which approval an $\mathrm{AB}$ system. Aliphatic protons at 2.95-3.47 ppm and a doublet at 4.65 $(\mathrm{d}, J=7.50 \mathrm{~Hz})$ show a $\beta$-glycosidic moiety. The correlation 4.65 with 152.7 noticed from the HMBC spectrum established a the glycosidic bond is between $\mathrm{C} 4$ and $\mathrm{C} 1$ '.

${ }^{1} \mathrm{H}$ NMR, (400 MHz, in DMSO-d6), $\delta_{\mathrm{H}} 6.67$ (d, $8.86 \mathrm{~Hz}, 2 \mathrm{H}, \mathrm{H} 2$ and $\mathrm{H} 6), 6.87(\mathrm{~d}, 8.86 \mathrm{~Hz}$, 2H, H3 and H5), 4.65 (d, $7.50 \mathrm{~Hz}, 1 \mathrm{H}, \mathrm{H1}{ }^{\prime}$ ), 2.93-2.97 (m, 1H, H2'), 3.09-3.13 (m, $1 \mathrm{H}$, H3'), 3.02-3.06 (m, 1H, H4'), 3.13-3.17 (m, 1H, H5'), 3.67-3.72 (m, 1H, H6'a), 3.43-3.47 $\left(\mathrm{m}, 1 \mathrm{H}, \mathrm{H}^{\prime} \mathrm{b}\right),{ }^{13} \mathrm{C}$ NMR $(100 \mathrm{MHz}$, in DMSO-d6) $\delta_{\mathrm{C}}$ 150.8, (C1), 115.9 (C2 and C6), 118.2 (C3 and C5), 152.7 (C4), 102.2 (C1'), 73.8 (C2'), 77.1 (C3'), 70.3 (C4'), 77.4 $\left(\mathrm{C} 5^{\prime}\right), 61.3\left(\mathrm{C}^{\prime}\right)$. The ${ }^{1} \mathrm{H}$ and ${ }^{13} \mathrm{C}$ NMR spectra were identical to those of arbutin (See Figure 2).

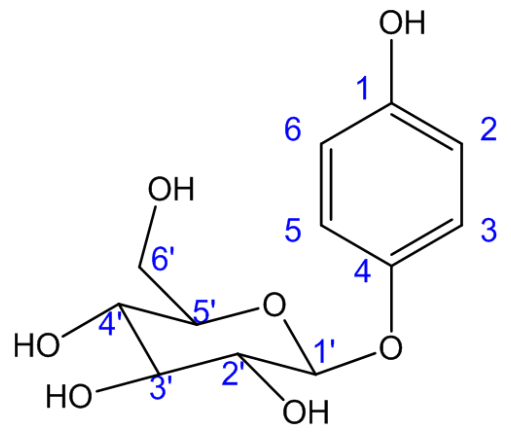

Figure 2. Chemical structure of arbutin 


\subsection{Quantitive analysis}

The results were given in Table 1. HPLC analysis showed that arbutin could be extracted effectively with methanol than cold water for two analyzed plant material. $O$. galegifolia calculated as \% arbutin content of dry biomass as follows $\% 6.86$ and $\% 5.66$ for
$O$. galegifolia and $O$. nitida, respectively. Arbutin is found in various plants such as Arctostaphylos uvaursi, Vaccinium vitis-idea, Pyrus communis. and some Origanum species. Bergenia crassifolia is one of richest arbutin has been found richer than $O$. nitida in the aspect of arbutin. The arbutin contents of plants were

Table 1. Quantitatively calculated arbutin content of $O$. nitida and O. galegifolia

\begin{tabular}{|l|l|l|c|}
\hline & Extraction solvent & $\mathrm{mg} / \mathrm{gr}$ extract & \% Dry biomass \\
\hline \multirow{2}{*}{ Onobrichys galegifolia } & Cold water & $128.22 \pm 1.44$ & 6.86 \\
\cline { 2 - 3 } & $\mathrm{MeOH}$ & $212.02 \pm 0.98$ & \\
\hline \multirow{2}{*}{ Onobrichys nitida } & Cold water & $99.41 \pm 1.22$ & \multirow{2}{*}{5.66} \\
\cline { 2 - 3 } & $\mathrm{MeOH}$ & $196.46 \pm 2.01$ & \\
\hline
\end{tabular}

containing plant ( \%20 of dry weight). sources of arbutin by \%5.66-6.86 arbutin According to our findings $O$. nitida and $O$. content of dry weights, respectively. galegifolia could be considered as new

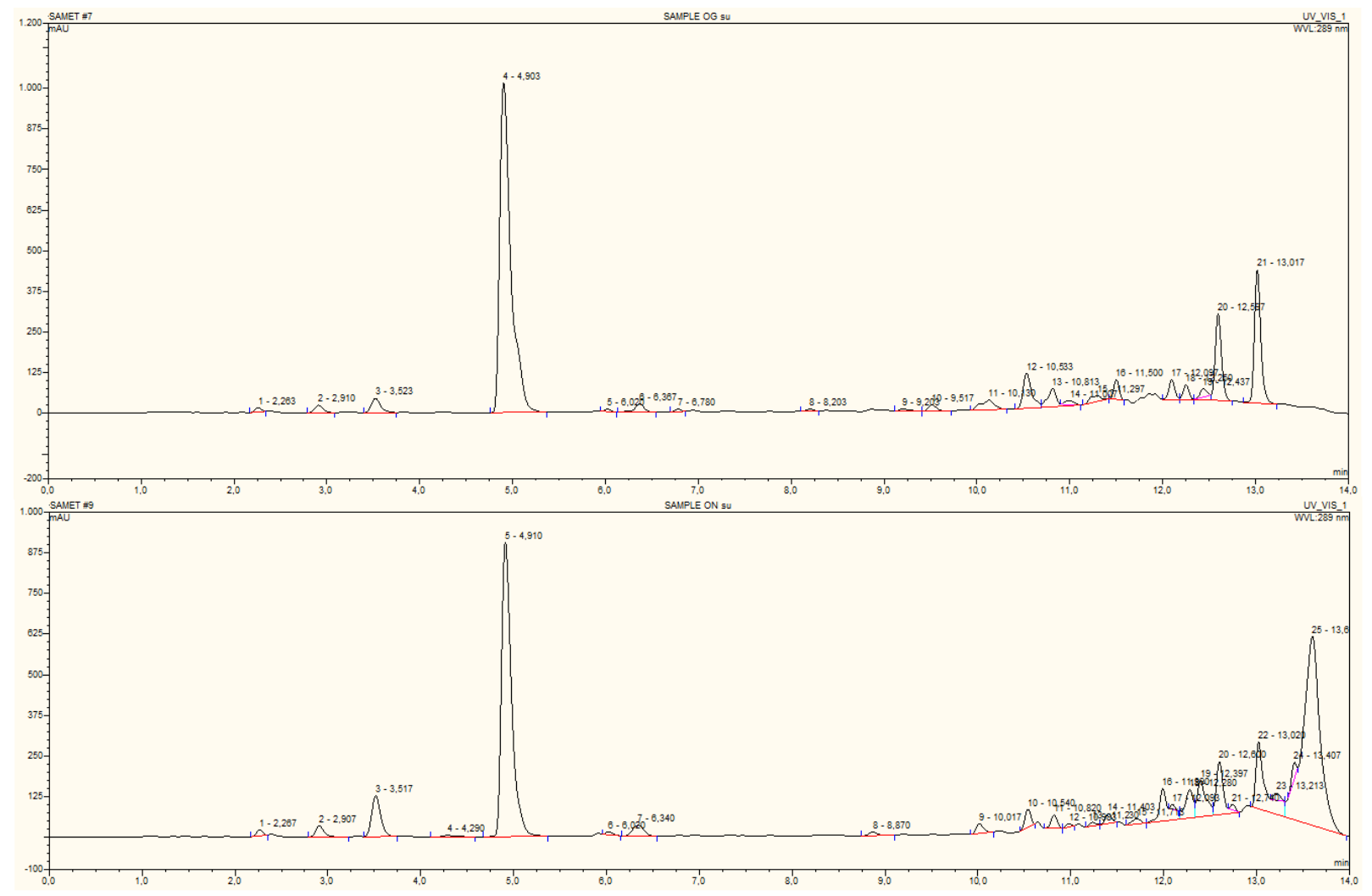

Figure 3. HPLC chromatograms of cold-water extracts of Onobrychis galegifolia and Onobrychis nitida $(290 \mathrm{~nm})$ 


\section{Conclusions}

Arbutin and polyphenolic content of some Onobrychis species were reported previously (Moniava 1970, Bol', Kompantsev et al. 1976, Luk'yanchikov 1982, Marais, Mueller-Harvey et al. 2000, Regos, Urbanella et al. 2009, Regos and Treutter 2010). Onobrychis nitida plant is an endemic species to Turkey flora (Kandemir 2009). Although some research has been carried out on HPLC analysis of chemical content of $O$. nitida (Kandemir, Türkmen et al. 2018) no single study exists which reports both occurrence and quantitative analysis of arbutin in $O$. nitida.

\section{References}

Bol', M. Y., et al. (1976). "Polyphenols of Onobrychis vassiltschenkoi and their polarographic determination." Chemistry of Natural Compounds 12(1): 91-92.

Kandemir, A. (2009). "The rediscovery of some taxa thought to have been extinct in Turkey." Turkish Journal of Botany 33(2): 113-122.
Kandemir, A., et al. (2018). "Analysis of phenolic compounds, antioxidant and antimicrobial properties of some endemic medicinal plants."

Luk'yanchikov, M. (1982). "Polyphenols of Onobrychis bobrovii." Chemistry of Natural Compounds 18(2): 237-237.

Marais, J. P., et al. (2000). "Polyphenols, condensed tannins, and other natural products in Onobrychis viciifolia (sainfoin)." Journal of Agricultural and Food Chemistry 48(8): 3440-3447.

Moniava, I. (1970). "Arbutin from Onobrychis kachetica." Chemistry of Natural Compounds 6(2): 270-270.

Regos, I. and D. Treutter (2010). "Optimization of a high-performance liquid chromatography method for the analysis of complex polyphenol mixtures and application for sainfoin extracts (Onobrychis viciifolia)." Journal of Chromatography A 1217(40): 6169-6177.

Regos, I., et al. (2009). "Identification and quantification of phenolic compounds from the forage legume sainfoin (Onobrychis viciifolia)." Journal of Agricultural and Food Chemistry 57(13): 5843-5852. 